\title{
Environmental justice and conceptions of the green economy
}

Article

Accepted Version

Environmental Justice and Conceptions of the Green Economy

Ehresman, T.G. and Okereke, C. (2015) Environmental justice and conceptions of the green economy. International

Environmental Agreements: Politics, Law and Economics, 15 (1). pp. 13-27. ISSN 1573-1553 doi:

https://doi.org/10.1007/s10784-014-9265-2 Available at https://centaur.reading.ac.uk/38519/

It is advisable to refer to the publisher's version if you intend to cite from the work. See Guidance on citing.

To link to this article DOI: http://dx.doi.org/10.1007/s10784-014-9265-2

Publisher: Springer

All outputs in CentAUR are protected by Intellectual Property Rights law, including copyright law. Copyright and IPR is retained by the creators or other copyright holders. Terms and conditions for use of this material are defined in the End User Agreement.

\section{www.reading.ac.uk/centaur}

\section{CentAUR}

Central Archive at the University of Reading 
Reading's research outputs online 


\section{Environmental Justice and Conceptions of the Green Economy}

\section{Timothy G. Ehresman}

Department of Politics

University of the South-Sewanee

Sewanee, TN 37383

USA

tgehresm@sewanee.edu

Tel: 931-598-1877

and

\section{Chukwumerije Okereke}

Department of Geography and Environmental Science

University of Reading

Whiteknights Campus

RG6 6AB

P.O. Box 433, Reading

c.okereke@ reading.ac.uk

Special Issue of International Environmental Agreements:

International Environmental Justice

and the Quest for a

Green Economy 


\begin{abstract}
.Abstract
Green economy has become one of the most fashionable terms in global environmental public policy discussions and forums. Despite this popularity, and its being selected as one of the organizing themes of the United Nations Rio+20 Conference in Brazil, June 2012, its prospects as an effective mobilization tool for global environmental sustainability scholarship and practice remains unclear. A major reason for this is that much like its precursor concepts such as environmental sustainability and sustainable development, green economy is a woolly concept which lends itself to many interpretations. Hence, rather than resolve long-standing controversies, green economy merely reinvigorates existing debates over the visions, actors and policies best suited to secure a more sustainable future for all. In this review article, we aim to fill an important gap in scholarship by suggesting various ways in which green economy may be organized and synthesized as a concept, and especially in terms of its relationship with the idea of social and environmental justice. Accordingly, we offer a systemization of possible interpretations of green economy mapped onto a synthesis of existing typologies of environmental justice. This classification provides the context for future analysis of which, and how, various notions of green economy link with various conceptions of justice.
\end{abstract}

Keywords: international environmental justice, green economy, social justice, sustainable development, Rio+20

Abbreviations

EKC Environmental Kuznets Curve

GDP Gross Domestic Product

GE Green Economy

OECD Organisation for Economic Cooperation and Development

UNEP United Nations Environment Programme 


\section{Introduction}

The increasing attention given to "green economy" as a possible new pattern for the pursuit of economic development at national and international levels underscores the not infrequent claim that the prevailing model of global economic growth is unsustainable and in need of revision (Piketty 2013; Jackson 2009). Deep controversies remains inter alia over what degree of adjustment is needed, which policy tools are most adequate and who is best placed to lead such a transition.

Policy and scholarship debates around the green economy have so far covered the source of finance needed for transition (Mendona 2009), the best incentive structure for motivating investment and innovation (Anex 2000; Elzen, Geels, and Green 2004), the technological approach and tools most adequate (Chen 2008; Anex 2000), and appropriate governance options at national and global levels (Bumpus, Taney, Pérez Henríquez and Okereke 2015). One of the central political questions about the green economy, and the question that impels this article, concerns its relationship with social and environmental justice. While questions of justice have long been of concern to international relations scholars, these have certainly become amplified and more urgent in the context of the politics and law of international environmental agreements as several contributions to this Journal indicate (see e.g. Kemfert and Tol 2002; Ringius, Torvanger and Underdal 2002; Matsui 2002; and Grasso 2011).

Debates about tools, polices and technology are often surrogates for deeper and more complex controversies about politics, power and justice (cf. Newell and Mulvaney 2013). While the bourgeoning 'just transition' scholarship highlights justice and equity concerns in the context of green economy, there remains a dearth of literature specifically addressing how these two 
concepts are connected. We suggest that a better understanding of the justice implications of the green economy requires first an integrative and systematic assessment of the different conceptions of the green economy and justice. This is because, much like precursor concepts such as environmental sustainability and sustainable development, green economy is an amorphous concept which lends itself to many interpretations. In other words, contrary to impressions conveyed in some mainstream literature (e.g. UNEP 2011) neither green economy nor green transition is monolithic. Rather, each concept is contested and multi-dimensional. Similarly justice is a notoriously malleable concept with many theories and interpretations.

The aim of this paper is to systemize key interpretations of green economy mapped onto a synthesis of typologies of social and environmental justice. This survey and classification should provide the context for more informed debate and analysis of the kind of green economy transition that should be promoted and how best to ensure equity and justice in the context of such a transition.

We begin by tracing the historical lineage of the concept of green economy, and then summarizing existing, if underdeveloped, categorizations of the green economy.

We then present our own typology of green economy and the allied or corresponding conception of distributional justice based on an extensive survey of the literature. Our typology also indicates visions of institutions, type of politics and environmental philosophy that are associated with these categories.

\section{Origin and Emerging Categorizations of GE}

Although the origins and essential foundations of green economy may be traced to the popularization of environmental concerns in advanced industrial society in the late 1960s and 
1970s (Harper-Anderson 2012), green economy was first expressly invoked in the 1989 piece Blueprint for a Green Economy (Pearce et.al. 1989). Michael Jacobs also employed the term in his 1991 book entitled "The green economy: Environment, sustainable development and the politics of the future". By the mid-1990s, labour union representatives explicitly called for recognition of the potential of 'green jobs' to boost national and global economies (Stevis and Felli 2015). Despite these efforts, however, the concept did not achieve wide usage. Ecological modernization gained popularity in the late 1990s (e.g. Mol 1996) as a needed qualification of business-as-usual global capitalism. This discourse entailed an emphasis on technological innovation to production techniques as a means of enhancing the environmental sustainability of economic activity. Despite notional affinities with ecological modernization, green economy was still not widely and expressly invoked.

It was in 2008, in the context of the global financial and economic crisis that green economy gained its popularity (Runnalls 2011). The principal impetus was the Green Economy Initiative launched by the United Nations Development Group, as one of nine UN-wide programmes to provide a $\mathrm{UN}$ response to the global economic crisis. A major outcome of this initiative was the UNEP blueprint on a global green economy which was published in 2011. The popularity of green economy reached a new level with the concept being adopted as a key organizing theme for the Rio+20 Conference in Brazil, June 2012.

At the same time, green economy also began to attract renewed and strong academic interest. Notable treatments include an examination of the relevance of green economy for domestic policy in Bangladesh (Ahmed 2013), China (Caia et al. 2011), the Arab world (Abaza, Saab and Zeitoon 2011), Mexico (Barkin and Fuente 2013), Peru (Borg Rasmussen 2012), Ireland (Davies and Mullin 2011), Taiwan (Chao, Ma and Heijungs 2014), and Southern Africa 
(Resnick, Tarp and Thurlow 2012). Green economy has also been examined in the context of international finance (Carraro, Favero and Massetti 2012), greentech clusters (Davies 2013), and even the use of airspace (Rule 2011). ${ }^{1}$

By way of laying the foundation for our discussion on justice, we note that the academic and policy discourse on the green economy reveals a general recognition of the indeterminacy of the concept and some attempt to categorize it. At least two categorizations are prominent: its transformative potential, and its relationship with sustainable development.

With respect to transformative potential at least three lines are discernible. The first is that which suggests that the green economy concept has radical transformative potential and is capable of inducing far reaching changes to the structure and practice of global capitalism. Bowen and Fankhauser (2011) argue that the green economy implies "a paradigm shift" and the need for "deep, structural and systemic" changes in the economy as opposed to the tinkering at the margins with which much of the extant literature on sustainability is associated (ibid: 1158).
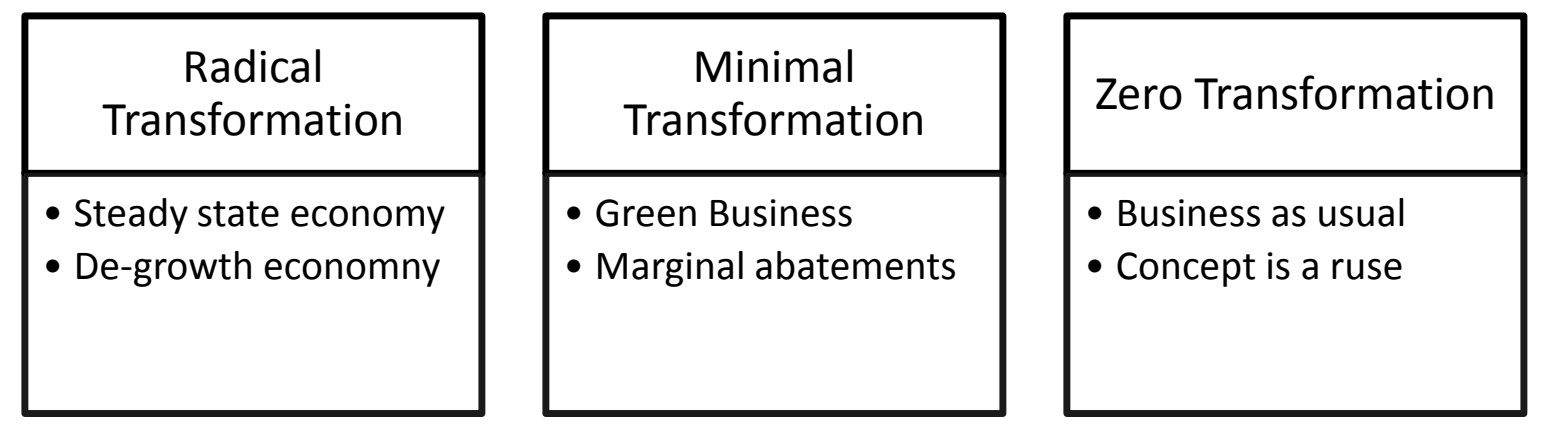

\section{Fig. 1 Green Economy's Transformative Potential}

In the second category, green economy is seen as having less transformative potential.

Here, it is argued that the prior commitment to neoliberal capitalism implies that only marginal

\footnotetext{
${ }^{1}$ Green economy has recently and usefully been differentiated from concepts such as 'Green New Deal' and 'Green Stimulus' (Tienhaara 2014). However, we do not take up these distinctions here because we believe the ramifications of each concept for justice are largely interchangeable.
} 
changes can be expected. Hence the green economy warrants little more than a continued progression of corporate activity towards more corporate social responsibility and green jobs. Barbier (2012) argues that the green economy - or at least the version that was articulated at the Rio+20 conference - was based squarely on the market model and would entail subordinating environmental sustainability to growth imperatives. This version, he argues cannot therefore countenance steady state or de-growth options. Similarly, Bernstein (2013) notes that insofar as Rio+20 sought to compromise and work with "features consistent with dominant liberal market norms" (14), 'green economy' is at best marginal, incapable of prompting real and lasting change.

Thirdly, the green economy has been characterized as nothing more than a cover for business as usual. In this view, green economy adds nothing but well-worn shibboleths to the debate over how to conceptualize the human-nature relationship. It is at best an incidental and merely apparent restraint on the excesses of the global economic impact on environment and society, and at worst a defusing of the intensity of urgent calls for environmentally-driven change by government and corporate actors who stand to gain from public invocations of policy nomenclature while the fundamental substance and structure of the global economy remains largely untouched (cf. Benton 1999). The emphasis on green growth is a false hope, and enduring environmental and social crises are in fact the result of the growth perspective (Jackson 2009). Green economy, in a principally free market modality, functions primarily to merely delay the inevitable social and environmental damage — indeed catastrophe — which will ensue when and if we fail to alter our prevailing economic direction (Evanoff 2011).

The second prominent way in which literature and public policy discourse have categorized the green economy is in terms of its relationship to sustainable development. Here 
again there are at least three distinct if sometimes overlapping classes. First, some have suggested that sustainable development is too broad and difficult to operationalize. Here, the green economy is hailed as a needed replacement. As the argument goes, green economy has the virtue of parsimony because it allows policymakers to focus on the economic pillar of sustainability (Borel-Saladin and Turok 2013: 213). In this view, green economy—with encouragement and sponsorship — can bring about needed change. In any event and pragmatically speaking, framing sustainability in the context of economic growth simply makes more sense post-crisis, eliciting broader support than demands for radical-only change. Thus green economy "is currently the most effective strategy for beginning to foster greater understanding and appreciation for the environmental and social problems facing us" (ibid: 218).
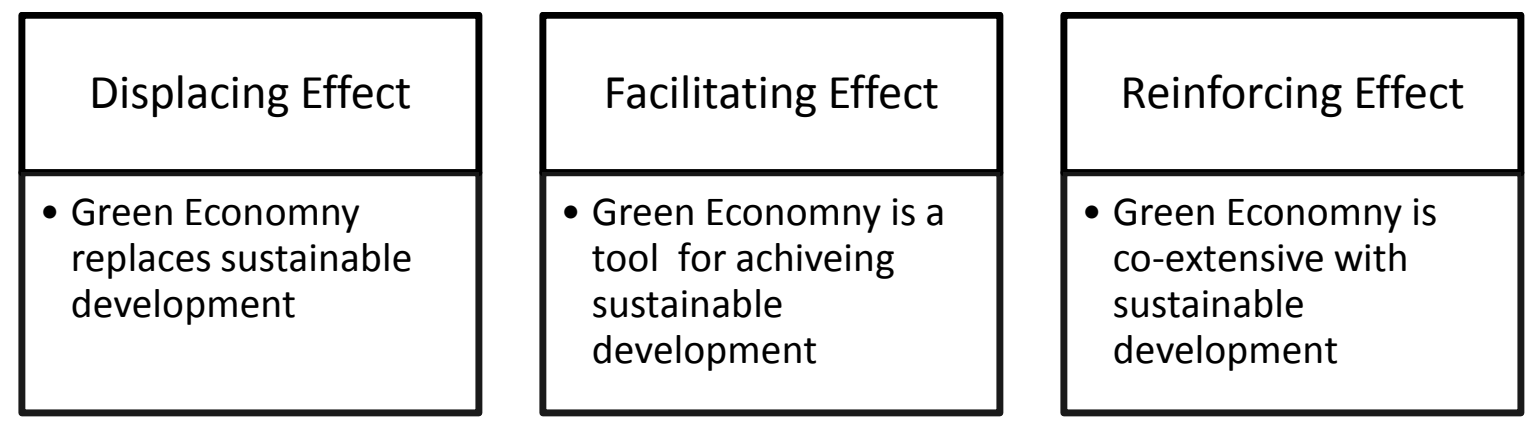

\section{Fig. 2 Green Economy's relationship with Sustainable Development}

Second, green economy can be seen as a tool for achieving sustainable development. Here, the notional influence and stature of sustainable development remains paramount and green economy is seen as either augmenting, or a tool for achieving, global sustainability. The UN Rio+20 Outcome Document is clear that sustainable development remains a central rallying point, seen as enabled and promoted by its sister concept - green economy (2012: 2 Para. 12; and 
9 Article III). Similarly, the OECD has suggested that green economy should be seen as facilitating rather than as a replacement for sustainable development (OECD 2011).

Third, green economy may be seen as synonymous and co-extensive with sustainable development. For these observers the two terms are largely fungible. For example, Halle (2011) contends that green economy is merely a re-labeling of sustainable development. Similarly, Abaza et.al (2011) suggest that green economy really adds nothing new to the concept of sustainable development while Brockington (2012) characterizes the UNEP report as promoting "mainstream sustainable development" (411).

We contend that while these putative categorizations offer useful insights, a more vital question for the green economy is about its relationship with social and environmental justice. Questions of justice must be at the heart of any discussion on transition in so far as it is evident that one of the greatest weaknesses of the current development model is that it has permitted or even facilitated the expansion of significant inequality both within and between nations (Reiff 2013; Picketty 2014; Sachs and Santarius 2007). There is the need, therefore, to carefully consider if, where and how policies aimed at encouraging a greener economy can better take account of the full range of justice impacts and prospects such a transition would generate. In order to advance such a debate, it is important to synthesize front-running interpretations of green economy and the notions of justice they evoke. It is to this task that we now turn.

\section{Green Economy, Justice, and a Systemization of Views}

The full range and variety of scholarly approaches to environmental justice in the context of environmental sustainability have been ably catalogued elsewhere (Dobson 1998; Harris 
2010; Okereke 2008; Clapp and Dauvergne 2011; Ehresman and Stevis 2011; Christoff 1996; Okereke and Dooley 2010). There are also several extensive treatments of conceptions of justice and their link with various international economic structures (Nagel 2005; Pogge 1989; Beitz 1999; Kapstein 2004). However, we think that a more concentrated emphasis on green economyjustice nexus is in order, particularly in light of the international momentum for transition to green economy. Our survey has produced the following categories (i) Thin Green Economy/ Market Justice; (ii) Moderate Green Economy/Egalitarian Justice; and (iii) Thick Green Economy/Structural Justice. Our typology also indicates visions of institutions, type of politics and environmental philosophy that are associated with these categories. Although we have sought to provide a description of fault lines and contours for general demarcations, there is a need to recognize that some areas overlap.

We decided to steer away from the labels of 'weak' and 'strong' - to avoid the allusion that a 'weak' green economy denotes an overall weak economy. We also tried to not use concepts such as 'shallow' and 'deep' - to avoid cross-meanings with the deep ecology literature.

\subsection{Thin Green Economy Perspective}

The Thin Green approach suggests that green economy is a potentially useful corrective for industry and government to address the negative environmental impacts of industrial activity (van der Ploega and Withagen 2013). However, the idea that a green economy warrants the fundamental restructuring of the global economic system is rejected. According to this view, promoting economic growth remains by far the best approach for tackling poverty and inequality. It is contended that higher incomes and economic growth generally indicate increasing human welfare (Arrow et al. 2010) and are themselves instrumental in ensuring the 
sustainable use of environmental resources (Hollander 2003). The main drivers of environmental degradation are poverty, a lack of economic growth, and governmental policies such as subsidies and tariffs which distort the ability of trade dynamism to guide the economy and society towards the most sustainable use of resources.

Scholars proposing the Thin Green Economy approach are quick to point out that they are not opposed to the search for environmental integrity. In fact they maintain that environmental sensitivity makes good business sense. The problem, they say, is that we are not allowing the free unseen hands of the market to correct externalities and drive the environmental policies and practices of individual firms (Bhagwati 2004).

Thin Green advocates consider that the 'truth' in their arguments is best illustrated by an empirical look at the environmental and related economic trajectory in the industrialized North over the past two centuries (e.g. Lomborg 2001: 6ff), noting that in fact ambient conditions are overall improving (Easterbrook 1995, 2003; Simon 1996). This relationship is modeled by some in the Environmental Kuznets Curve (EKC) (Bao 2008, Van Alstine and Neumayer 2008, Boyce 2008). Notwithstanding a vast literature on the putative validity of the EKC (see e.g. the recent review of work on the EKC in Chowdhury and Moran 2012), advocates of the EKC (notwithstanding a number of challenges to this view) point to the industrial world and note the vast improvements in air and water quality, sanitation, and the reduction of industrial pollutants which have materialized under the aegis of vastly increased wealth and individual economic welfare over the past 150 years or so.

Based on this, it is suggested that growth that does not harm the environment is possible. "The hope is that a Green New Deal which invests billions in projects that protect the environment will generate a triple whammy: growth in conventional income will get a boost and 
will lead to lots of extra jobs; the protection of the natural environment will by itself not necessarily go at the cost of growth but may even enhance it and Green Growth provides a higher sustainability level for the global economy than business as usual" (van der Ploega and Withagen 2013: 117, emphasis original). Correct pricing, valuation of nature and encouraging socio-technical technological innovation are the key tools to realizing this vision (ibid: 118).

Clearly, then, the Thin Green approach rejects the notion of ecological limits, suggesting in the lineage of the ecological modernization discourse that technological solutions will be found to resource limits, and that history is replete with examples of the ways in which scarcity drove innovation and adjustment, to the betterment of humankind (e.g. Simon 1992).

As to implications for international justice, dominant here is what may be most clearly referred to as 'market justice.' In this view the core of justice is founded on individual rights (Nozick 1974), seen as including in particular property rights, which translates into economic rights. An individual retains environmental rights to the extent they are consistent with economic rights, and in this approach the two are seen as complementary since the operation of market-based economic activity will produce the best long-term environmental outcomes. The proper role of the state is limited to preserving these rights and protecting the fruit of their exercise (see e.g. discussion in Garcia 2003). Justice, then is more an instrument of permission than of direction: permitting the market to continue in an only somewhat mitigated form with its fundamentals unchallenged and unaltered, and individual economic and thus environmental freedom impinged to the minimum possible extent. Internationally the best result is for the global economy —in all of its domestic applications— to be allowed to rest on market liberal premises and to operate under that rubric.

\subsection{Thick Green Economy Perspective}


The Thick Green approach is generally formulated as a counterpoint to the Thin Green approach, which is seen as the dominant paradigm (Barry 2012; Brockington 2012; Evanoff 2011; Lorek and Spangenberg 2014). The Thick Green economy approach is premised on at least three related arguments. First is the view that there are hard and intractable limits to the natural resource base upon which the present developmental trajectory depends (Barry 2012; Jackson 2009). Here it is contended that many planets and several times the natural resource reserves known to exist would be required for the world's poor to progress along the same path to consumption, wealth and waste as was followed in the industrial North.

Second, it is argued that the pace of production—a significant portion of which occurs with deleterious environmental consequences in the less-developed South (Evanoff 2011; Khor 1996) - has facilitated high and unsustainable rates of individual consumption and waste in the North (Iles 2004; Princen, Maniates and Conca 2002; Cafaro 2005).

Third and relatedly, the central causative or at least facilitative factor inducing environmental crisis is the global liberal economy with its unending quest for capital accumulation. Western capitalism and its celebration of individual material preference, taste, and even obsession drive the excesses in and environmental impacts of the lifestyles in not only the industrial North, but also among elites in the global South. Given this premise, Thick Green economy scholars contest the notion that change is meaningfully possible in a context of everincreasing consumption and expanding markets" (Brockington 2012, p.412). The alternative model proposed is economic contraction, or "managed recession" (Brockington 2012, Kallis 2011, Schneider, Martinez-Alier, \& Kallis 2011).

On this alternative model, the basic neoclassical premises that supply and demand justify an un-moderated range of market transactions in the name of individual liberty and maximum 
overall systemic efficiency must be reconsidered. Kosoy et.al. (2012), Davies and Mullin (2011) and Victor and Jackson (2012) among many others argue that the mainstream conception of the green economy is entirely misguided insofar as it fails to adjust to the scientific evidence of the limitations of the endless growth paradigm. In fact Kosoy et.al. (2012) suggest that the dominant notion of the green economy is hardly anything more than a repackaging of "Keynesianism or neo-liberal austerity" (2012: 74, quoting Kallis 2011). They insist that "there are many essential human goals and common goods that cannot be adequately discussed using the language of economics" (ibid: 75). Davies and Mullin (2011) as well as Lorek and Spangenberg (2014), on their own part, attack the ecological modernization root of Thin and Moderate Green Economy for its neglect of nature conservation and its obsession with "developing the environment and stimulating innovation" (Davies and Mullin: 798).

Furthermore they argue that the so called Green New Deal is somewhat illusory, as new green jobs will locate primarily in high tech sectors and such arenas of work can hardly benefit “those on the margins of mainstream economy"(Davies and Mullin 2011: 798).

Of the three Green Economy perspectives identified in the body of literature surveyed, the Thick Green Scholars are by far the most vocal in calling for a stronger attention to justice in the new global green economy transition. We have labeled the form of justice implicated here as 'structural justice' as what must be altered is the very foundation and structure of the global economy. In their view, mere policy changes are incapable of adequately reorienting and realigning international capital to environmental and social justice needs. Victor and Jackson (2012) have criticized the version of green economy espoused by UNEP, arguing that it is far too moderate, growth oriented, and insensitive to the deep and inextricable links between equity and 
environmental targets. They contend that "a truly green economy is one in which social equity and environmental objectives are met" (ibid: 14).

Similarly, Wapner (2011) observes that "much of the world produces, buys, sells, and uses goods and services in ways that enhance injustice and undermine the organic infrastructure that supports life on earth" (525). He argues that anchoring the market solely to the forces of supply and demand makes it difficult to effectively project social justice and ecological issues. He says that under the mainstream green economy approaches, justice comes into play only in the most extreme circumstances where external actors have forced the issue. For Wapner, a truly green economy would entail embedding the global financial system in a socio-ecological context, where social justice and ecological concerns are taken up in an extra-market, empowered sphere.

In the same vein, Barkin and Fuente (2013) argue that by valuing nature purely in economic terms, mainstream green economy approach remains "firmly tied to global markets and prices with their mechanisms for concentrating wealth and power" (208). Based on the analysis of community forest management in Mexico, they conclude that "environmental justice requires different paradigms and the incorporation of the producers themselves into the process" (Ibid). Davies and Mullin (2011) contend that questions of justice have so far been suppressed in the mainstream green economy transition process, which for the most part is "predominantly technical and financial rather than social or political” (794). For Aşici and Bünül (2012), what might be needed is a more revolutionary eco-socialism approach that dethrones the reformist emphasis on renewables and the sort of green economy propounded by UN agencies which, in their view, is nothing more than "green capitalism" (296). 
Thick Green advocates thus call for more justice and democracy, “empowerment of marginalised groups, and international collaboration to solve the global environmental and social problems" (Lorek and Spangenberg 2014: 36). This involves degrowth, rather than growth, and the valuing of non-market activities such as sharing and voluntary work. These more socially embedded activities could be part of a social revolution that would re-establish "regenerative relationships with nature"-lessons that we would do well to learn again from more traditional cultures (Milani 2000: xxi). And "the green community, characterized by freedom and equality among human beings as well as respect for non-human nature, is imagined as breaking free of the formal economy in favour of a self-sufficient informal economy. This image, however utopian, is based on the contention that it is profoundly misleading to restrict the idea of economic activity to the formal economy" (Torgerson 2001: 477).

\begin{tabular}{|c|c|c|c|}
\hline & $\begin{array}{c}\text { Thick Green } \\
\text { Economy }\end{array}$ & $\begin{array}{c}\text { Moderate Green } \\
\text { Economy }\end{array}$ & $\begin{array}{l}\text { Thin Green } \\
\text { Economy }\end{array}$ \\
\hline $\begin{array}{l}\text { Understanding of } \\
\text { Economy }\end{array}$ & $\begin{array}{l}\text {-Abandon a full commitment } \\
\text { to neoclassical economics, } \\
\text {-Turn to 'de-growth' or } \\
\text { 'steady state' economics }\end{array}$ & $\begin{array}{l}\text {-Green economy provides a } \\
\text { useful paradigm within which } \\
\text { to conceptualize and actualize } \\
\text { changes in economic policy } \\
\text { and practice. Some level of } \\
\text { intervention in the global } \\
\text { economy will be necessary to } \\
\text { capture the justice potential of } \\
\text { green economy. }\end{array}$ & $\begin{array}{l}\text {-Overall neoliberal ethos } \\
\text { remains the best hope for } \\
\text { environment and global } \\
\text { poverty reduction. } \\
\text {-Green economy is an } \\
\text { acceptable addition to a global } \\
\text { business model }\end{array}$ \\
\hline $\begin{array}{l}\text { Understanding of } \\
\text { International } \\
\text { Environmental Justice }\end{array}$ & Structural Justice & Egalitarian Justice & Market Justice \\
\hline Role of State & $\begin{array}{l}\text {-State and global civil society } \\
\text { play central role } \\
\text {-Emphasis on local economy }\end{array}$ & $\begin{array}{l}\text {-Emphasis on building and } \\
\text { strengthening global } \\
\text { governance institutions }\end{array}$ & $\begin{array}{l}\text {-Minimal state role } \\
\text {-Full market operation } \\
\text {-Avoid price distortion } \\
\text { through subsidies } \\
\end{array}$ \\
\hline $\begin{array}{l}\text { Ecological vs. } \\
\text { Environmental Economics }\end{array}$ & Ecological Economics & & Environmental economics \\
\hline Politics & Revolutionary & Reformist & $\begin{array}{l}\text { Incremental change, when } \\
\text { necessary }\end{array}$ \\
\hline Eco-Philosophy & $\begin{array}{l}\text {-Ecocentric and } \\
\text { anthropocentric } \\
\text {-Limits }\end{array}$ & $\begin{array}{l}\text {-Enlightened } \\
\text { anthropocentrism } \\
\text {-Limits }\end{array}$ & $\begin{array}{l}\text {-Anthropocentric } \\
\text {-Innovation and human } \\
\text { ingenuity }\end{array}$ \\
\hline
\end{tabular}




\section{Fig. 3 Green Economy and International Environmental Justice}

\subsection{Moderate Green Economy Perspective}

Occupying a middle ground between the Thick and Thin Green approaches, the Moderate Green Economy perspective recognizes that a purely market based approach is insufficient for securing global environmental sustainability and social justice. However, it rejects a wholesale abandonment of the prevailing economic system arguing that, with some significant reforms, the system is durable and sufficiently resilient to accommodate environmental and social justice concerns (Abaza, Saab and Zeitoon 2011; Ahmed 2013; Meléndez-Ortiz 2011; UNEP 2011).

Moderate Green Economy scholars suggest that the urgency of, and brevity of time needed to address pressing global environmental, justice and human development goals do not warrant devoting effort in search of how to alter what is essentially a durable and fundamentally acceptable system (Halle 2011; Haas 2012; OECD 2011). The best chance for success they argue lies in trying to find solutions from within rather than from outside the system (Newell and Paterson 2010). "It is eminently clear" says Halle (2011), with respect to neoliberalism, "that something new is needed, but it is not always easy to let go of the familiar" (473).

Many in the Moderate Green economy approach contend either explicitly or implicitly that liberal economic and political values hold at a fundamental level the greatest promise for the emancipation of the global poor and oppressed (Pop, Dina and Martinc 2011; UNEP 2011), though Moderate Greens oppose raw neoliberalism as an undergirding premise for green economy (Bigg 2011; Borg Rasmussen 2012).

Abaza, Saab and Zeitoon (2011) tie the concept of green economy for the Arab world into the triple bottom line - an emphasis on simultaneously meeting economic, environmental 
and social goals. They suggest that "in contrast to mainstream economic planning, which deals with the environment in isolation, the green economy aligns the macroeconomic policies of the state with environmental and social policy goals" (xv). Similarly, in a study of shrimp farming in Bangladesh, Ahmed (2013) invokes a triple bottom line understanding of green economy suggesting that "the thematic focus of green economy is sustainable development [growthbased], environment and poverty alleviation" (Ahmed 2013: 35). For Charnovitz (2012) and Haas (2012) the hallmark of the new global green economy should be sustainable production and consumption. Similarly, Meléndez-Ortiz (2011) suggests that "by capturing the negative externalities of our natural resource use, our economic institutions and systems should be managed so that we can live off the dividends instead" (479).

Green economy scholarship in this strand adopts environmental economics as a standard guide for policy making while allowing that market instruments will not themselves always be adequate to chart a clear path forward. Business as usual is insufficient if green economy is to serve as a vehicle for ameliorative change (e.g. Bigg 2011: 460). Critically, this model allows for government intervention at national and international levels and, as Borel-Saladin and Turok (2013) put it, fosters "an environment conducive to greener economic decisions from both the private sector and the public" (213).

Because of the important guiding and interventionist role reserved for states in this view, a lot of emphasis is devoted to the search for the right institutions that can help deliver sustainability and social justice goals across various geographical scales. Puppim de Oliveira et.al. (2013) articulate this position well when they declare that "a green economy goes beyond simply greening parts of the conventional economy. It will require a broader understanding of how the economy functions, including not only the appropriate pricing of environmental 
externalities, but creation of the right institutions that steer the economy to lead to a fair distribution of the limited resources" (150).

This scholarship is taken up in initiatives for crossing traditional institutional and conceptual boundaries in a form of 'earth system governance,' wherein the governing of environmental and thus economic systems transcends traditional understandings limited to hierarchical state function and process (Biermann 2002, Biermann et.al. 2010). Instrumental strategies may include strengthening international environmental law_public and private — and the institutional mandate and capacity of the United Nations Environment Programme (or even creating a supervening World Environment Organization, as the environmental counterpart to the WTO_see e.g. Biermann 2002).

In line with a core liberal philosophy, moderate green economy favours an amalgam of different forms of liberal egalitarian approaches to justice. This includes among other, Rawlsian egalitarianism (Harper-Anderson 2012, Ehresman 2010, Jones 2008; Pogge 1989; Rawls 1971; Dower 1998; Okereke 2008); capabilities approach (Sen 1999; Nussbaum 2000, 2006); human rights justice (Woods 2006) and inclusive development.

Moderate Greens emphasize the existence of a moral link — indeed obligation — within and between countries (Dower, 1998). They argue following Rawls' established difference principle - that the inequality permitted within the global liberal economy must be seen to be acceptable only to the extent that the greater resources held by the more privileged are employed at a minimum to increase the level of absolute welfare of the world's poor, and where possible to narrow the inequality gap (Pogge 1989). For them closing this gap requires attention to both distributive and procedural justice within the global regimes of trade, investment, and 
environmental policy making (Biermann et.al. 2012; Garcia 2003, 2013; Okereke 2008; Pogge 1989).

This approach would embrace the call for a green economy as a welcome attenuation of raw economic pursuit, in the interest of seeking greater equity among nations economically and thus environmentally. Many in this approach would note that, despite its validity in some sectors, the EKC does not capture the extent to which cleaner environments in the North are premised on dirtier environments elsewhere in the world where the goods the North consumes are produced, and the fact that for some pollutants, such as carbon, there is no essential and automatic EKC downslope to hope for (World Bank 2012).

The capabilities approach to justice emphasizes the need to recognize and ameliorate the disparate capacity of individuals across borders in order to enable them exercise the rights and freedoms inherent in liberal precepts and assumptions. If liberal propositions concerning the value and centrality of individual freedom and liberty are to be seen as valid within the specter of sustained inequity among nations and deplorable life chances for so many, some adjustment of the neoliberal vision is essential if the liberal model itself is to retain the intellectual pedigree of a worldview that is both honest and humane.

\section{Discussion}

The outcome of Rio+20 suggests that the global community is equivocal on not only the prospects but also the very meaning of green economy, and the ways in which it implicates issues of justice. While the Conference did not articulate a definitive identification of the meaning of green economy, a consensus emerged at that time regarding its place in the landscape of vocabulary, thought and debate regarding the global environment. In particular, the Rio+20 
Outcome Document, prepared and agreed upon at the Rio+20 conference and adopted by the UN General Assembly on July 27, 2012, reiterates the importance of a green economy as subsidiary to sustainable development more generally (UN 2012). The Outcome Document further clarifies the needed focus going forward, identifying poverty eradication as the principal challenge facing the nations of the world today and an indispensable stepping stone to achieving sustainable development (Para. 2). Recognizing that people are at the "centre of sustainable development," the Outcome Document expressed commitment by states to "strive for a world that is just, equitable and inclusive” (Para. 6, emphasis added). In so doing, the Conference representatives also expressly affirmed their ongoing commitment to green economy "in the context of sustainable development" (Para. 12). Thus the global community may be seen to be settling on an understanding of green economy as a tool — a particular dimension — of sustainable development.

This affirmation notwithstanding, we hold that the green economy discourse presents a unique opportunity to address justice concerns, if only because it has rekindled interest in and attention to the relationship among equity, economy and environment among actors at a multiplicity of levels of society — from the local to the global.

\section{Conclusion}

It is fair to surmise that the implication of green economy for global environmental sustainability discourse and practice remains unclear. The term remains subject to different interpretations in different venues, and is harnessed to widely differing policy aims and objectives. Hence, rather than resolve long-standing controversies, green economy merely reinvigorates existing debates over the visions, actors and policies best suited to secure a more sustainable future for all. We 
have suggested that a key controversy surrounding the green economy is about how the concept relates to the idea of social and environmental justice. Our systemization of possible interpretations of green economy, then, provides the context for future analysis of which, and how, various notions of green economy link with various conceptions of justice.

\section{Acknowledgements}

The authors wish to thank Dimitris Stevis and Dale Jamieson, as well as the editorial board of this Journal, for their helpful and insightful comments on an earlier draft of this article. Any errors or omissions remain the sole responsibility of the authors. 


\section{References}

Abaza, H., Saab, N., \& Zeitoon, B. (Eds.). (2011). Arab environment 4 green economy: Sustainable transition in a changing Arab world. Beruit: Arab Forum for Environment and Development.

Ahmed, N. (2013). Linking prawn and shrimp farming towards a green economy in Bangladesh: Confronting climate change. Ocean \& Coastal Management, 75, 33-42.

Anex, R. P. (2000). Stimulating innovation in green technology policy alternatives and opportunities. American Behavioral Scientist, 44(2), 188-212.

Arrow, K. J., Dasgupta, P., Goulder, L. H., Mumford, K., \& Oleson, K. (2010). China, the US, and sustainability: Perspectives based on comprehensive wealth. In G. Heal (Ed.), Is economic growth sustainable? New York: Palgrave Macmillan.

Aşıc1, A. A., \& Bünül, Z. (2012). Green New Deal: A green way out of the crisis? Environmental Policy and Governance, 22, 295-306.

Bao, Q., Chen, Y., \& Song, L. (2008). The environmental consequences of foreign direct investment in China. In L. Song, \& W. T. Woo (Eds.), China's Dilemma: Economic Growth, the Environment and Climate Change: Brookings Institution Press.

Barbier, E. B. (2012). The green economy post Rio+20. Science, 338, 887-888.

Barkin, D., \& Fuente, M. (2013). Community forest management: Can the green economy contribute to environmental justice? Natural Resources Forum, 37, 200-210.

Barry, J. (2012). The politics of actually existing unsustainability: Human flourishing in a climate-changed, carbon-constrained world. Oxford: Oxford University Press.

Beitz, C. R. (1999). International liberalism and distributive justice: A survey of recent thought. World Politics, 51(2), 269-296.

Benton, T. (1999). Sustainable development and the accumulation of capital: Reconciling the irreconcilable? In A. Dobson (Ed.), Fairness and futurity: Essays on environmental sustainability and social justice. Oxford: Oxford University Press.

Bernstein, S. (2013). Rio+20: Sustainable development in a time of multilateral decline. Global Environmental Politics, 13(4), 12-21.

Bhagwati, J. (2004). In Defense of Globalization. Oxford: Oxford University Press.

Biermann, F. (2002). Strengthening green global governance in a disparate world society: Would a World Environment Organisation benefit the South? International Environmental Agreements, 2, 297-315.

Biermann, F., Betsill, M. M., Gupta, J., Kanie, N., Lebel, L., Liverman, D., et al. (2010). Earth system governance: A research framework. International Environmental Agreements, 10, 277-298.

Bigg, T. (2011). Development governance and the green economy: A matter of life and death? Review of Policy Research, 28(5), 459-465.

Borel-Saladin, J. M., \& Turok, I. N. (2013). The green economy: Incremental change or transformation? Environmental Policy and Governance, 23, 209-220.

Borg Rasmussen, M. (2012). Greening the economy: Articulation and the problem of governance in the Andes. Mountain Research and Development, 32(2), 149-157.

Bowen, A., \& Fankhauser, S. (2011). The green growth narrative: Paradigm shift or just spin? Global Environmental Change, 21, 1157-1159. 
Boyce, J. K. (2008). Globalization and the Environment: Convergence or Divergence? In K. P. Gallagher (Ed.), Handbook on Trade and the Environment. Cheltenham: Edward Elgar Publishing Limited.

Brockington, D. (2012). A radically conservative vision? The challenge of UNEP's Towards a Green Economy. Development and Change, 43(1), 409-422.

Bumpus, A., Tansey, J., Pérez Henríquez, B. L., \& Okereke, C. (Eds.). (2015). Carbon governance, Climate change and business transformation. London: Routledge.

Cafaro, P. (2005). Gluttony, arrogance, greed, and apathy: An exploration of environmenal vice. In R. Sandler, \& P. Cafaro (Eds.), Environmental virtue ethics. Lanham: Rowman \& Littlefield Publishers, Inc.

Caia, W., Wanga, C., Chen, J., \& Wanga, S. (2011). Green economy and green jobs: Myth or reality? The case of China's power generation sector. Energy, 36, 5994-6003.

Carraro, C., Favero, A., \& Massetti, E. (2012). Investments and public finance in a green, low carbon, economy. Energy Economics, 34, S15-S28.

Chao, C.-W., Ma, H.-w., \& Heijungs, R. (2014). The green economy mirage? Examining the environmental implications of low carbon growth plans in Taiwan. Journal of Industrial Ecology, 17(6), 835-845.

Charnovitz, S. (2012). Organizing for the green economy: What an international green economy organization could add. The Journal of Environment Development, 21(1), 44-47.

Chen, Y. S. (2008). The driver of green innovation and green image: green core competence. Journal of Business Ethics, 81(3), 531-543.

Chowdhury, R. R., \& Moran, E. F. (2012). Turning the curve: A critical review of Kuznets approaches. Applied Geography, 32, 3-11.

Christoff, P. (1996). Ecological modernisation, ecological modernities. Environmental Politics, 5(3), 476-500.

Clapp, J., \& Dauvergne, P. (2011). Paths to a green world: The political economy of the global environment (2nd ed.) (2nd ed.). Cambridge MA: The MIT Press.

Davies, A. R. (2013). Cleantech clusters: Transformational assemblages for a just, green economy or just business as usual? Global Environmental Change, 23, 1285-1295.

Davies, A. R., \& Mullin, S. J. (2011). Greening the economy: interrogating sustainability innovations beyond the mainstream. Journal of Economic Geography, 11, 793-816.

Desombre, E. R. (2011). Global environmental governance for a new green economy. Review of Policy Research, 28(5), 467-472.

Dobson, A. (1998). Justice and the environment. Oxford: Oxford University Press, Inc.

Dower, N. (1998). World ethics: The new agenda. Edinburgh: Edinburgh University Press.

Easterbrook, G. (1995). A moment on the earth: The coming age of environmental optimism. New York: Penguin.

Easterbrook, G. (2003). The progress paradox. New York: Random House.

Ehresman, T. (2010). Liberal international environmental justice and foreign direct investment at the International Finance Corporation. Paper presented at the International Studies Association Conference, Montreal,

Ehresman, T., \& Stevis, D. (2011). International environmental justice. In G. Kutting (Ed.), Global environmental politics: Concepts, Theories and Case Studies (pp. 87-104). New York: Routledge.

Elzen, B., Geels, F. W., \& Green, K. (Eds.). (2004). System innovation and the transition to sustainability: Theory, evidence and policy. Northampton: Edward Elgar Publishing. 
Evanoff, R. (2011). Bioregionalism and Global Ethics: A Transactional Approach to Achieving Ecological Sustainability, Social Justice, and Human Well-being. New York: Routledge.

Garcia, F. J. (2003). Trade, inequality, and justice: Toward a liberal theory of just trade. Ardsley: Transnational Publishers.

Garcia, F. J. (2013). Global justice and international economic law: Three takes. Cambridge: Cambridge University Press.

Grasso, M. (2011). The role of justice in the North-South conflict in climate change: The case of negotiations on the adaptation fund. International Environmental Agreements, 11(4), 361-377.

Haas, P. M. (2012). The political economy of ecology: Prospects for transforming the world economy at Rio plus 20. Global Policy, 3(1), 94-101.

Halle, M. (2011). Accountability in the green economy. Review of Policy Research, 28(5), 473477.

Harper-Anderson, E. (2012). Exploring what greening the economy means for African American workers, entrepreneurs, and communities. Economic Development Quarterly, 26(2), $162-$ 177.

Harris, P. G. (2010). World ethics and climate change: From international to global justice. Edinburgh: Edinburgh University Press.

Hollander, J. M. (2003). The Real Environmental Crisis: Why Poverty, Not Affluence, Is the Environment's Number One Enemy. Berkeley: University of California Press.

Iles, A. (2004). Mapping Environmental Justice in Technology Flows: Computer Waste Impacts in Asia. Global Environmental Politics, 4(4), 76-107.

Jackson, T. (2009). Prosperity without growth: Economics for a finite planet. London: Earthscan.

Jacobs, M. (1991). The green economy: Environment, sustainable development and the politics of the future. London: Pluto Press.

Jones, V. (2008). The green collar economy: How one solution can fix our two biggest problems. New York: Harper Collins Publishers.

Kallis, G. (2011). In defence of degrowth. Ecological Economics, 70(5), 873-880.

Kapstein, E. B. (2004). Models of international economic justice. Ethics \& International Affairs, 18(2), 79-92.

Kemfert, C. \& Tol, R.S.J. (2002). Equity, international trade and climate policy. International Environmental Agreements: Politics, Law and Economics, 2(1), 23-48.

Khor, M. (1996). Global economy and the Third World. In J. Mander, \& E. Goldsmith (Eds.), The case against the global economy: And for a turn toward the local. San Francisco: Sierra Club Books.

Kosoy, N., Brown, P. G., Bosselmann, K., Duraiappah, A., Mackey, B., Martinez-Alier, J., et al. (2012). Pillars for a flourishing Earth: planetary boundaries, economic growth delusion and green economy. Current Opinion in Environmental Sustainability, 4, 74-79.

Lomborg, B. (2001). The skeptical environmentalist. Cambridge: Cambridge University Press.

Lorek, S., \& Spangenberg, J. H. (2014). Sustainable consumption within a sustainable economy-beyond green growth and green economies. Journal of Cleaner Production, 63, 33-44.

Matsui, Y. (2002). Some aspects of the principle of "Common But Differentiated Responsibilities." International Environmental Agreements: Politics, Law and Economics, 2(2), 151-170. 
Meléndez-Ortiz, R. (2011). Governance of international trade for the green economy. Review of Policy Research, 28(5), 479-486.

Mendona, M. (2009). Powering the green economy: The feed-in tariff handbook. London: Routledge.

Milani, B. (2000). Designing the green economy: The post-industrial alternative to corporate globalization. Lanham: Rowman \& Littlefield Publishers Inc.

Mol, A. (1996). Ecological modernisation and institutional reflexivity; Environmental reform in the Late Modern Age. Environmental Politics, 5(2), 302-323.

Nagel, T. (2005). The problem of global justice. Philosophy and Public Affairs, 33(2), 113-147.

Newell, P., \& Mulvaney, D. (2013). The political economy of the 'just transition'. The Geographical Journal, 179(2), 132-140.

Newell, P., \& Paterson, M. (2010). Climate capitalism: Global warming and the transformation of the global economy. Cambridge: Cambridge University Press.

Nozick, R. (1974). Anarchy, state, and utopia. New York: Basic Books.

Nussbaum, M. (2000). Women and human development: The capabilities approach. Cambridge: Cambridge University Press.

Nussbaum, M. (2006). Frontiers of justice: Disability, nationality, species membership. Cambridge: Harvard University Press.

OECD. (2011). Towards green growth. Paris: OECD.

Okereke, C. (2008). Global justice and neoliberal environmental governance: Sustainable development, ethics and international co-operation. London/New York: Routledge.

Okereke, C., \& Dooley, K. (2010). Principles of justice in proposals and policy approaches to avoided deforestation: Towards a post-Kyoto climate agreement. Global Environmental Change, 20(1), 82-95.

Pearce, D., Markandya, A., \& Barbier, E. B. (1989). Blueprint for a green economy. London: Earthscan Publications Ltd.

Piketty, T. (2013). The return of capital and the dynamics of inequality. ESPIRIT(11), 85-95.

Piketty, T. (2014). Capital in the twenty-first century. Cambridge, MA: The Belknap Press of Harvard University Press.

Pogge, T. W. (1989). Realizing Rawls. Ithaca: Cornell University Press.

Pop, O., Dina, G. C., \& Martinc, C. (2011). Promoting the corporate social responsibility for a green economy and innovative jobs. Procedia Social and Behavioral Sciences, 15, 10201023.

Princen, T., Maniates, M., \& Conca, K. (2002). Confronting Consumption. In T. Princen, M. Maniates, \& K. Conca (Eds.), Confronting Consumption. Cambridge MA: The MIT Press.

Puppim de Oliveira, J. A., Doll, C. N. H., Balaban, O., Jiang, P., Dreyfus, M., Suwa, A., et al. (2013). Green economy and governance in cities: assessing good governance in key urban economic processes. Journal of Cleaner Production, 58, 138-152.

Rawls, J. (1971). A Theory of justice. Cambridge: Harvard University Press.

Reiff, M. R. (2013). Exploitation and economic justice in the liberal capitalist state. Oxford: Oxford University Press.

Resnick, D., Tarp, F., \& Thurlow, J. (2012). The political economy of green growth: Cases from Southern Africa. Public Administration and Development, 32, 215-228. 
Ringius, L., Torvanga, A. \& Underdal, A. (2002). Burden sharing \& fairness principles in international climate policy. International Environmental Agreements: Politics, Law and Economics, 2(1), 1-22

Rule, T. A. (2011). Airspace in a green economy. UCLA Law Review, 59, 270-320.

Runnalls, D. (2011). Environment and economy: Joined at the hip or just strange bedfellows. S.A.P.I.EN.S, 4(2), 1-10.

Sachs, W., \& Santarius, T. (Eds.). (2007). Fair Future: Resource Conflicts, Security and Global Justice. London: Zed Books.

Schneider, F., Martinez-Alier, J., \& Kallis, G. (20011). Sustainable degrowth. Journal of Industrial Ecology, 15(5), 654-656.

Sen, A. (1999). Development as freedom. New York: Anchor Books.

Simon, J. L. (1992). Population and development in poor countries. Princeton: Princeton University Press.

Simon, J. L. (1996). The ultimate resource 2. Princeton: Princeton University Press.

Stevis, D., \& Felli, R. (2015). Global labor unions and just transition to a green economy. International Environmental Agreements: Politics, Law and Economics, 15(_),

Tienhaara, K. (2013). Varieties of green capitalism: Economy and environment in the wake of the global financial crisis. Environmental Politics, 23(2), 187-204.

Torgerson, D. (2001). Rethinking politics for a green economy: A political approach to radical reform. Social Policy \& Administration, 35(5), 472-489.

UN. (September 11, 2012 (Reissued January 17, 2013)). The future we want (A/RES/66/288). New York: United Nations.

UNEP (2011). Towards a green economy: Pathways to sustainable development and poverty eradication: A Synthesis for Policy Makers. Nairobi: UNEP.

Van Alstine, J., \& Neumayer, E. (2008). The Environmental Kuznets Curve. In K. P. Gallagher (Ed.), Handbook on trade and the environment. Cheltenham: Edward Elgar Publishing Limited.

van der Ploega, R., \& Withagen, C. (2013). Green Growth, Green Paradox and the global economic crisis. Environmental Innovation and Societal Transitions, 6, 116-119.

Victor, P. A., \& Jackson, T. (2012). A commentary on UNEP's green economy scenarios. Ecological Economics, 77, 11-15.

Wapner, P. (2011). Civil society and the emergent green economy. Review of Policy Research, 28(5), 525-530.

Woods, K. (2006). What does the language of human rights bring to campaigns for environmental justice? Environmental Politics, 15(4), 572-591.

World Bank. (2012). Inclusive green growth: The pathway to sustainable development. Washington D.C.: World Bank. 